Geological Society, London, Special Publications Online First

\title{
Use of multiple oxygen isotope proxies for elucidating Arctic Cretaceous palaeo-hydrology
}

Celina A. Suarez, G. A. Ludvigson, L. A. Gonzalez, A. R. Fiorillo, P. P. Flaig and P. J. Mccarthy

Geological Society, London, Special Publications, first published June 17, 2013; doi 10.1144/SP382.3

$\begin{array}{ll}\begin{array}{l}\text { Email alerting } \\ \text { service }\end{array} & \begin{array}{l}\text { click here to receive free e-mail alerts when } \\ \text { new articles cite this article }\end{array} \\ \begin{array}{l}\text { Permission } \\ \text { request }\end{array} & \begin{array}{l}\text { click here to seek permission to re-use all or } \\ \text { part of this article }\end{array} \\ \text { Subscribe } & \begin{array}{l}\text { click here to subscribe to Geological Society, } \\ \text { London, Special Publications or the Lyell } \\ \text { Collection }\end{array}\end{array}$

How to cite click here for further information about Online First and how to cite articles

Notes

(C) The Geological Society of London 2013 


\title{
Use of multiple oxygen isotope proxies for elucidating Arctic Cretaceous palaeo-hydrology
}

\author{
CELINA A. SUAREZ ${ }^{1 *}$, G. A. LUDVIGSON ${ }^{2}$, L. A. GONZALEZ ${ }^{3}$, A. R. FIORILLO ${ }^{4}$, \\ P. P. FLAIG ${ }^{5} \&$ P. J. MCCARTHY 6 \\ ${ }^{1}$ Department of Geosciences, University of Arkansas, 346 Arkansas Avenue, \\ Fayetteville, AR 72701, USA \\ ${ }^{2}$ Kansas Geological Survey, 1930 Constant Avenue, Lawrence, KS 66047-3726, USA \\ ${ }^{3}$ Department of Geology, University of Kansas, 1475 Jayhawk Boulevard, \\ Lawrence, KS 66045-7594, USA \\ ${ }^{4}$ Museum of Nature and Science, PO Box 151469, Dallas, TX 75315, USA \\ ${ }^{5}$ Bureau of Economic Geology, Jackson School of Geosciences, University of Texas, \\ Austin, TX 78758, USA \\ ${ }^{6}$ Department of Geology \& Geophysics, University of Alaska, Fairbanks, AK 99775-5780, USA \\ *Corresponding author (e-mail: casuarez@uark.edu)
}

\begin{abstract}
Stable oxygen isotope analysis of siderite and dinosaur tooth enamel phosphate from the Campanian-Maastrichtian Prince Creek Formation, Alaska, USA, are analysed to determine the palaeohydrology of the ancient Colville Basin north of the Ancestral Brooks Range. $\delta^{18} \mathrm{O}$ of freshwater siderites relative to V-PDB ranges between -14.86 and $-16.21 \%$. Dinosaur tooth enamel $\delta{ }^{18} \mathrm{O}$ from three different sites (Kikak-Tegoseak, Pediomys Point, Liscomb) range between $+3.9 \%$ and $+10.2 .0 \%$. $\delta^{18} \mathrm{O}_{\text {meteoric water }}$ are calculated from $\delta^{18} \mathrm{O}_{\text {siderite }}$ that formed at seasonal temperatures ranging from -2 to $14.5^{\circ} \mathrm{C}$, with a mean annual temperature of $6.3{ }^{\circ} \mathrm{C}$. At $6.3{ }^{\circ} \mathrm{C}$, the $\delta^{18} \mathrm{O}_{\mathrm{w}}$ calculated from siderite ranged between -22.23 and $-20.89 \%$ V-SMOW. Ingested water compositions are estimated from dinosaur teeth assuming body temperatures of $37{ }^{\circ} \mathrm{C}$ and local relative humidity of $77.5 \%$, resulting in values ranging from -28.7 to $-20.4 \%$ o V-SMOW, suggesting consumption of meteoric water and orographically depleted runoff from the Brooks Range. The ranges in calculated $\delta^{18} \mathrm{O}_{\text {meteoric water are compatible between the two }}$ proxies, and are mutually corroborating evidence of extremely ${ }^{18} \mathrm{O}$-depleted precipitation at high latitudes during the Late Cretaceous relative to those generated using general circulation models. This depletion is proposed to result from increased rainout effects from an intensified hydrological cycle, which probably played a role in sustaining polar warmth.
\end{abstract}

Supplementary material: Parameters used for generation of equations compared to Kohn (1996) can be found at http://www.geolsoc.org.uk/SUP18642

Stable isotopic proxies are invaluable tools for understanding past and current climates. Pedogenic carbonates (siderite and calcite) are commonly used to determine the isotopic composition of meteoric water (Lohmann 1988; Hays \& Grossman 1991; Ludvigson et al. 1998; Ufnar et al. 2004a; Suarez et al. 2011). When analysed over a range of latitudes, the resulting isotopic gradients can be used to determine global isotopic groundwater gradients. This gradient is related to the isotopic composition of the precipitation, which is itself related to temperature gradients, humidity and, in some instances, orographic effects.

Isotopic studies of the Cretaceous are of particular importance because future climatic conditions
(Kiehl 2011) are predicted to approach those $\left(p \mathrm{CO}_{2}\right.$, temperature) seen in the various greenhouse worlds of the Cretaceous. Several studies on the Cretaceous climate have revealed shallow equatorial-topole air and ocean temperature gradients (Wolfe \& Upchurch 1987; Amiot et al. 2004; Jenkyns et al. 2004; Pucéat et al. 2007), while others have indicated equator-to-pole precipitation $\delta^{18} \mathrm{O}$ gradients that are steeper than the modern climate system (Ludvigson et al. 1998; Ufnar et al. 2002; Suarez et al. 2011). This steep gradient has been explained as resulting from increased rainout, thereby increasing latent heat transport from the equator to the poles during greenhouse conditions (Ufnar et al. 2004b). These conclusions are based on empirical 


\section{A. SUAREZ ET AL.}

data, but general circulation models (GCMs) with isotopic capabilities have not been able to reproduce the steep isotopic gradient (Poulsen et al. 2007) at high latitudes. The inability of Earth system models to simulate empirically derived data has been explained by postulating local orographic effects as having confounded the high latitude data set. Consequently, additional studies of highlatitude regional climates are important for better understanding the disparity between GCM results and empirically derived data. Can the addition of vertebrate stable isotope proxies help to better understand regional palaeohydrology in the context of global climate change?

The sensitivity of the Arctic to climate changes makes it an ideal place to investigate past greenhouse states of the Earth. The Arctic preserves sediments deposited in greenhouse states, including the Palaeocene-Eocene thermal maximum (PETM) and the Cretaceous (the focus of this study) (Ufnar et al. 2004a; Pagani et al. 2006; Jahren et al. 2009). Investigation of these past climates suggests that during exceptional warmth, the Arctic was devoid of ice caps and sustained considerable biodiversity atypical of high latitudes today (e.g. lush deciduous forests in the middle Eocene (Jahren et al. 2010) and champsosaurs in the Cenomanian-Turonian (Tarduno et al. 1998; Vandermark et al. 2007)). The lack of ice caps, which decreases albedo, and the presence of dark-coloured vegetation, which increases insolation, acted as a positive feedback that helped sustain these warm climates of the Arctic (Hay \& DeConto 1999). As current $p \mathrm{CO}_{2}$ and temperatures increase, the not-too-distant future of the Arctic may become increasingly similar to the Arctic of the Cretaceous (Kiehl 2011).

The use of vertebrate remains as proxy data has some advantages over other palaeo proxies. Phosphate tends to be more resistant to diagenesis (Kolodny et al. 1996; Sharp et al. 2000) and may be a reliable proxy for water $\delta^{18} \mathrm{O}$. Also, thermoregulating animals that grow their phosphate at a constant or near-constant body temperature can be analysed without having to determine temperature independently. As land-dwelling animals get their water from a variety of sources, they can also sample the full spectrum of freshwater isotopic compositions of a particular region (Barrick et al. 1999).

This study uses the vertebrate remains of dinosaurs from the Arctic Prince Creek Formation (PCF, late Campanian to early Maastrichthian) as an additional proxy for surface-water isotopic compositions to augment data from pedogenic siderites (Ufnar et al. 2004a). The $\delta^{18} \mathrm{O}$ composition of phosphate from tooth enamel is used to calculate ingested surface water, and is compared to meteoric water values estimated from pedogenic siderite preserved in the PCF. The isotopic compositions of vertebrates and pedogenic carbonates from other foreland basin settings have been used to identify local orographic effects (Suarez et al. 2012). Therefore, the comparison of vertebrate ingested water with local groundwater is carried out to determine the range in isotopic compositions of surface waters, and to determine if there is a significant orographic effect on meteoric water from the ancestral Brooks Range. Comparisons to estimates of the $\delta^{18} \mathrm{O}$ of meteoric water from the underlying Nanushuk Formation (Albian-Cenomanian) are also made to determine whether the $\delta^{18} \mathrm{O}$ of PCF meteoric waters are as depleted in ${ }^{18} \mathrm{O}$ during the slightly cooler Late Campanian-Early Maastrichtian interval, and from sampling sites much further removed from the ancestral Brooks Range than those initially studied by Ufnar et al. (2004a).

\section{Stable isotopes in vertebrate bioapatite}

The isotopic composition of continental vertebrates is primarily controlled by ingested surface water/ living water and relative humidity (Kohn 1996). Offsets in $\delta^{18} \mathrm{O}_{\mathrm{w}}$ across the landscape can be recorded in bioapatites of the taxa that live in or consume it. As a result, the isotopic composition of vertebrate tooth enamel can be used to determine the range of the isotopic composition of surface water. Pedogenic calcite and siderite are known to record the average or slightly ${ }^{18} \mathrm{O}$-enriched endmember (in the case of calcite) isotopic composition of meteoric water (Lohmann 1988; Cerling \& Quade 1993; Cojan et al. 2003; Breecker et al. 2009; Suarez et al. 2009). Because pedogenic carbonates form in one location, they are less likely to record a wide range in the surface water isotopic composition, for example, from river water draining mountainous regions v. precipitation. Large-bodied thermoregulating terrestrial animals (non-aquatic) all demonstrate a similar relationship between ingested surface water and the $\delta^{18} \mathrm{O}$ of tooth phosphate (Kohn 1996), with the dominant influences for $\delta^{18} \mathrm{O}_{\mathrm{p}}$ being surface water, diet and relative humidity. Terrestrial animal body water tends to be enriched compared to local drinking water as a result of water loss by panting or transcutaneous water loss (evaporative enrichment). This trend, however, is highly dependent on humidity. Herbivore enamel tends to be enriched relative to carnivores because of the consumption of isotopically ${ }^{18} \mathrm{O}$-enriched plant leaves. Leaf water tends to be ${ }^{18} \mathrm{O}$-enriched due to evaporation of water during photosynthesis, with the degree of enrichment again being highly dependent on relative humidity (low humidity = highly enriched leaf water). Source water can be significantly ${ }^{18} \mathrm{O}$-depleted relative to local meteoric (rain) water if animals are 
consuming a significant portion of water from rivers sourced from high elevations where precipitation is depleted due to orographic rainout, cooler temperatures and/or melting snow (e.g. Dettman \& Lohmann 2000). As a result, the analysis of landdwelling vertebrates can be used to determine the range of regional hydrology, which is not available from the analysis of pedogenic carbonates. Thus, the combination of terrestrial vertebrate enamel and pedogenic siderites from the PCF is used to determine the range in palaeohydrology in the Campanian-Maastrichtian Arctic.

\section{Geological/tectonic and palaeoclimatic setting}

\section{Geological and tectonic setting}

The PCF is an alluvial succession deposited on a tidally influenced, high-latitude coastal plain in what is now known as the Colville Basin (Flaig et al. 2011). These sediments were shed during the rise of the ancestral Brooks Range (Fig. 1), which, during the Cretaceous, was a few hundred kilometres to the south (Fiorillo et al. 2010a). The ancestral Brooks Range was at least $1.5 \mathrm{~km}$ in elevation (Spicer 2003). Regionally, the PCF dips c. $3^{\circ}$ to the north (Fiorillo et al. 2010a; Gangloff \& Fiorillo 2010). It interfingers with the shallow marine Schrader Bluff Formation. Both formations are unconformably overlain by the Pliocene-Holocene Gubik Formation along the Colville River (Fiorillo et al. $2010 a$ ). The palaeo-latitude of Cretaceous rocks in this area is thought to be between $82^{\circ}$ and $85^{\circ} \mathrm{N}$ (Witte et al. 1987; Besse \& Courtillot 1991; Rich et al. 2002; Spicer \& Herman 2010). Ash layers in the vicinity of the Liscomb Bonebed returned weighted mean $\mathrm{K}-\mathrm{Ar}$ and ${ }^{40} \mathrm{Ar} /{ }^{39} \mathrm{Ar}$ ages of $69.1 \pm 0.3 \mathrm{Ma}$ (Conrad et al. 1990) and $69.2 \pm$ $0.5 \mathrm{Ma}$ (Flaig 2010), which is consistent with an Early Maastrichtian age (Maastrichtian = 70.665.5 Ma, ICS 2010 Geologic Time Scale) suggested by palynological data (Frederiksen 1990; Fiorillo et al. 2010a, b; Flaig et al. 2013).

The PCF was deposited on a high-latitude Arctic coastal plain (Flaig et al. 2011). Occasional marine transgression and marine influence on sedimentation is evidenced by the tidal influence in fluvial deposits and the presence of jarosite, pyrite and gypsum (as a pyrite weathering product), all of which increase in abundance up-section near the contact between the PCF and the overlying Schrader Bluff Formation (Flaig 2010; Flaig et al. 2011). PCF palaeoenvironments include meandering trunk channels, meandering and fixed distributary channels, crevasse splays, levees, swamps, small lakes and ponds, and poorly developed palaeosols with redoxomorphic features (Fiorillo et al. 2010a; Flaig 2010; Flaig et al. 2011). Trunk channel are 13+-m-thick, fining-upward successions containing basal lags with trough cross-bedded sandstones, inclined heterolithic stratification (IHS), convolute bedding, isolated bone fragments, logs, wood impressions and plant fragments (Flaig et al. 2011). Meandering distributary channels are thinner (2-6 $\mathrm{m}$ thick) and finer-grained, but also contain IHS. Third-order fixed distributary channels are the thinnest channel-form deposits (1.5-3.0 m thick) and lack prominent lateral accretion surfaces, containing only rare IHS. Crevasse splays are thinner interbedded siltstone and mudstone deposits. Levees are characterized by tabular sandstones up to $1 \mathrm{~m}$ thick overlain by successive intervals of olive-grey to dark brown siltstone and sandy siltstone. Abundant root traces, plant fragments, bioturbation and ferruginous nodules suggest weak soil development on splays and levees. Organic-rich floodplain deposits include organic-rich siltstone, carbonaceous shale, mudstone and coal, recording deposition in floodplain lakes, ponds, swamps and weak palaeosol development. The majority of bone beds are found encased in crevasse splays or overbank flood facies (Fiorillo et al. 2010a, b; Flaig 2010; Flaig et al. 2011).

Palaeosols of the PCF are similar to modern entisols, inceptisols and potential acid sulphate soils (Flaig et al. 2011). Palaeosols show redoximorphic features that are characteristic of alternating waterlogged and well-drained periods (Fiorillo et al. $2010 a$ ).

The majority of vertebrate remains analysed in this study come from three dinosaur quarries (Fig. 1): Kikak-Tegoseak, Liscomb Bonebed and Pediomys Point. Based on a regional dip of $3^{\circ}$ to the north, the site furthest to the south, KikakTegoseak is the oldest site and separated by hundreds of metres from the next stratigraphically higher site, Pediomys Point, which is separated by hundreds of metres from the uppermost site, Liscomb Bonebed. Unfortunately, incomplete, semicontinuous exposures along the Colville River do not allow for direct correlation of the stratigraphy between the three sites.

The Kikak-Tegoseak quarry contains floodplain facies including rooted very fine sandstone and siltstone. Bones show no signs of significant abrasion or weathering (no higher than weathering level 2), but do show some root etching and borings reminiscent of dermistid beetles. The majority of the remains from Kikak-Tegoseak are from the centrosaurine ceratopsian Pachyrhinosaurus (Fiorillo et al. 2010a, b). The large size of the associated bones and fine-grained matrix suggests that whole or partial carcasses floated into the site carried by relatively low-energy currents. 
South

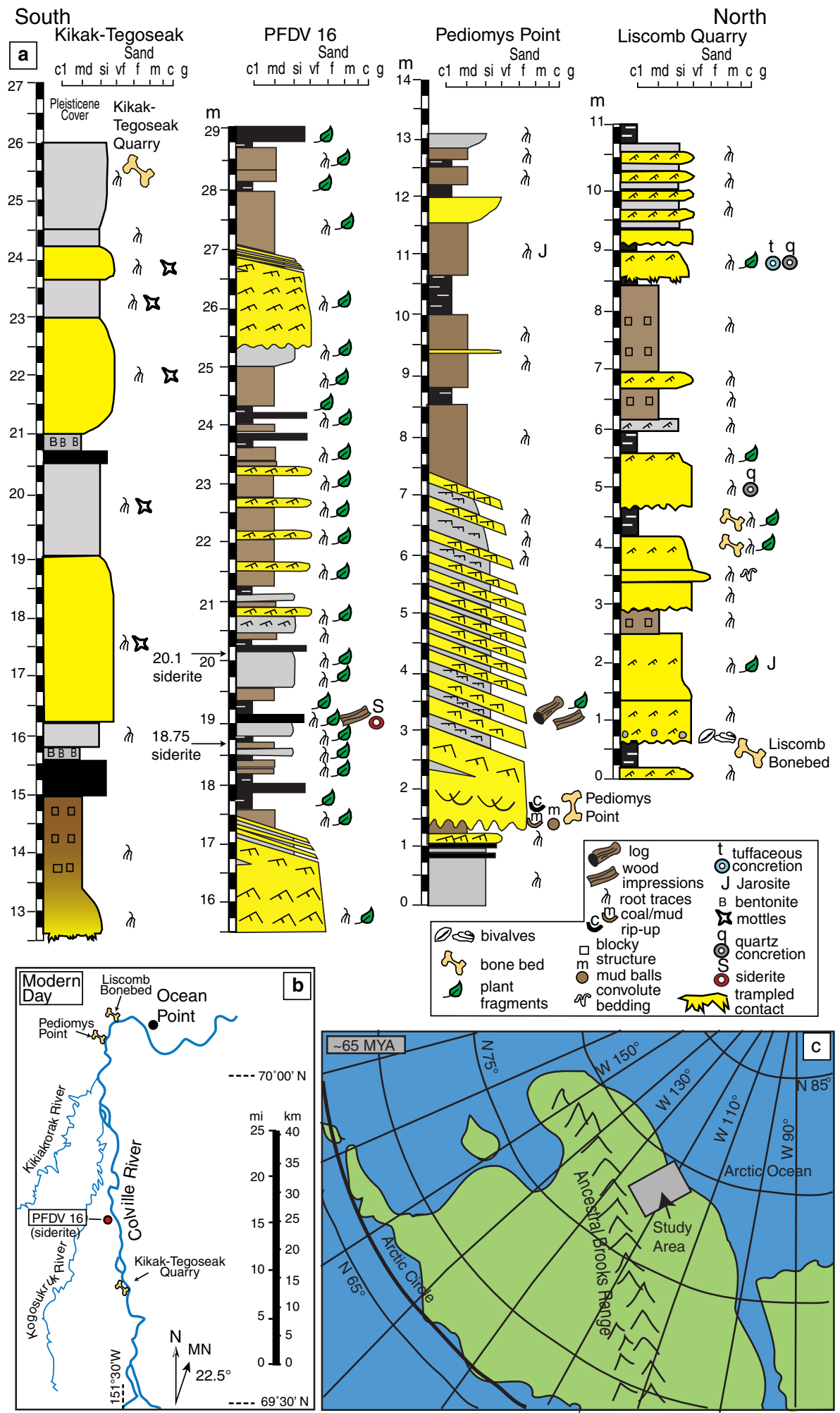


Pediomys Point contains fine- to mediumgrained sandstone, siltstone and mudstone deposited in meandering distributary channels, mud-filled abandoned channels and interdistributary environments that include crevasse splays, small lakes or ponds, swamps, floodplain palaeosols and ashfall deposits (Flaig 2010). Abundant jarosite (altered pyrite) and rare brackish-water clams and gastropods suggest a marine influence and a distal coastal plain setting. Fossils from Pediomys Point include the teeth of osteichthyans, dromaeosaurs, hypsilophodonts, pachycephalosaurs, hadrosaurids and mammals.

The Liscomb Bonebed contains organics (6.8$10.5 \%$ total organic content, TOC) sandy, argillaceous tuffaceous siltstone and mudstone. Most clays are smectitic and the presence of pyrite and jarosite indicates that it was close to the marine interface. Taphonomic study of the site suggests it was a mass mortality of sub-adult to juvenile Edmontosaurus, which were deposited by overbank floods (Gangloff \& Fiorillo 2010). Nearby ashes indicate an approximate age of $69.1 \pm 0.3 \mathrm{Ma}$ for sediments (Conrad et al. 1990; Flaig 2010).

\section{Palaeoclimatic, palaeoenvironmental setting and fauna}

Palaeo-temperatures, based on plant remains, suggest the Campanian-Maastrichtian North Slope of Alaska ranged from a cold month mean no colder than $-2{ }^{\circ} \mathrm{C}$ to a warm month mean of $14.5^{\circ} \mathrm{C}$, and averaged $6.3 \pm 2.2^{\circ} \mathrm{C}$ (based on the CLAMP and $\mathrm{TEX}_{86}$ analysis of Spicer \& Herman (2010)), which is in general agreement with earlier leaf physiognomy work (Spicer \& Parirish 1990). Precipitation estimates for the PCF ranged between 500 to $1500 \mathrm{~mm} / \mathrm{yr}$ (Spicer \& Parrish 1990). Globally, there is evidence for two warming events in the Maastrichtian (Li \& Keller 1998; Barrera \& Savin 1999; Nordt et al. 2003; Wilf et al. 2003) that may overlap with the timing of the PCF deposition. The older of these two warming events occurred between 69.5 and $68.5 \mathrm{Ma}$ and is associated with increases in atmospheric $p \mathrm{CO}_{2}$ concentrations of 1000-1200 ppmv (Nordt et al. 2003). This increase in $p \mathrm{CO}_{2}$ may have caused global mean annual temperatures to be $c .22{ }^{\circ} \mathrm{C}$ and is correlated with an increase in ocean temperatures of $c .3{ }^{\circ} \mathrm{C}$ and associated with the initiation of increased volcanic activity in the Indian Deccan traps (Hofman et al. 2000). This $p \mathrm{CO}_{2}$ and temperature peak is also correlated to the mid-Maastrichtian Event, in which a minor extinction occurred prior to the more extreme late Maastrichtian extinction event (Frank \& Arthur 1999; Keller 2001; Bralower et al. 2002). Although the $69 \mathrm{Ma}$ global warming event increased temperatures relative to the Santonian, mean annual temperatures (MATs) during PCF deposition were not as high as in the Aptian-Albian global warming event, when the MAT during deposition of the Nanushuk Formation was $c .11{ }^{\circ} \mathrm{C}$ (Wolfe \& Upchurch 1987; Spicer \& Corfield 1992) or during deposition of the Turonian-Coniacian Tuluvak Formation, which may have been even warmer with a MAT of $c .13^{\circ} \mathrm{C}$ (Parrish et al. 1987; Spicer \& Parrish 1990). This is also evidenced by the lack of turtle or crocodile remains in the PCF (Fiorillo et al. 2010a; Gangloff \& Fiorillo 2010). Turtles and crocodiles are present in the Nanushuk and Tuluvak formations (Gangloff \& Fiorillo 2010); they do not live in areas with prolonged nearfreezing seasons (Markwick 1998).

The PCF is characterized by a high quantity of low-diversity vertebrate fauna, with the majority of vertebrate fauna being dinosaurian (Fiorillo et al. $2010 a, b$; Gangloff \& Fiorillo 2010). Of the dinosaurian fauna, the majority of herbivores are either Pachyrhinosaurus or Edmontosaurus, with some remains of hypsilophodont and other unidentified hadrosaurs. Carnivorous species include tyrannosaurids such as Albertosaurus, as well as smaller maniraptorans such as Troodon and the dromaeosaurid Sauronitholestes (Phillips 2003; Fiorillo et al. $2010 a, b)$. Some mammalian remains such as the marsupial Pediomys have also been discovered, as well as unidentified osteichthyes fish and chondrichthyes remains (Gangloff \& Fiorillo 2010). Flora included coniferous forests on coastal plains, with broad-leafed deciduous flora in the riparian areas and an understorey of ferns and angiosperms (Spicer \& Herman 2010; Flaig 2010).

\section{Materials and methods}

\section{Materials}

Tooth samples were provided by the Museum of Nature and Science, Dallas, Texas, USA. Samples include the teeth attributable to Troodon, Dromaeosaurus and a tyrannosaurid, as well as teeth attributable to Pachyrhinosaurus, Edmontosaurus and unidentified hypsilophodontids, hadrosaurids and ornithopods. Material came from three main sites

Fig. 1. Location and stratigraphy. (a) Representative stratigraphic sections of bonebed sites and siderite localities from south to north. (b) Locations of sites for modern-day geography. (c) Palaeogeographic reconstruction for c. 65Ma. (Modified from Google Earth Paleogeography Gallery, Blakey 2011.) 


\section{A. SUAREZ ET $A L$.}

(from oldest to youngest): Kikak-Tegoseak, Pediomys Point and Liscomb Bonebed. Additionally, one tooth, found as float along the Colville River, was added to the analysis, and data for several large theropod (probably tyrannosaurid) teeth from Fricke \& Rogers (2000) were added to the data set. Crocodile and turtle remains have not been recovered from the PCF and were not included in this study. Edmontosaurus, hadrosaurid, ornithopods and hypsilophontid teeth were grouped together as 'non-ceratopsian herbivores'. Primary siderite cement and spherosiderites were analysed from two different stratigraphic levels in the PFDV-16 (Fig. 1b) measured section. Eight samples from $18.75 \mathrm{~m}$ above the Colville River datum and ten samples from $20.10 \mathrm{~m}$ above the Colville River datum were micromilled for isotopic analysis.

\section{Analytical methods and equations}

When possible, at least 10 individuals per taxa were analysed in attempts to determine the range in seasonal variability (Clementz \& Koch 2001; Levin et al. 2006; Kohn \& Dettman 2007). When 10 individuals could not be sampled, at least 3-5 serially sampled teeth were analysed, as required to resolve the seasonal variability and range in $\delta^{18} \mathrm{O}_{\mathrm{p}}$ of a particular taxa per stratigraphic level (Clementz \& Koch 2001; Levin et al. 2006; Kohn \& Dettman 2007). This is also the minimum number required to obtain an error of c. $1.3 \%$, which is the average standard deviation of $\delta^{18} \mathrm{O}_{\text {enamel }}$ (Levin et al. 2006). Approximately 200-500 $\mu \mathrm{g}$ of enamel powder was milled using a hand-held slow-speed drill. Phosphate samples were converted to silver phosphate following the method of O'Neil et al. (1994), as modified by Bassett et al. (2007). Silver phosphate samples were analysed at the W. M. Keck Paleoenvironmental and Environmental Stable Isotope Laboratory at the University of Kansas, Department of Geology, on a Thermo high-temperature conversion elemental analyser (TC/EA) connected to a ThermoFinnigan MAT 253 continuousflow mass spectrometer, and at the Stable Isotope Laboratory at the University of California, Santa Cruz, on a TC/EA connected to a ThermoFinnigan Delta Plus XP. Phosphate $\delta^{18} \mathrm{O}$ is reported in parts per thousand $(\% \circ)$ relative to $\mathrm{V}$-SMOW. Samples were calibrated with a combination of organic standards (e.g. IAEA-601) and calibrated phosphate standards (e.g. Acros $\mathrm{Ag}_{3} \mathrm{PO}_{4}$ and NIST 120c). NIST $120 \mathrm{c}$ was monitored as a quality control standard and is better than $\pm 0.3 \%$ V-SMOW, producing an average value of $22.5 \pm 0.3 \%$. This is higher than the most recently accepted value for NIST 120c of c. 21.7\% (Lécuyer 2004; Lécuyer et al. 2007; Halas et al. 2011). There has been some ambiguity as to the correct NIST $120 \mathrm{c}$ value because of variations depending on both the analysis method (conventional fluorination, reaction with graphite in sealed silica tubes, or high-temperature reduction using a TC/EA) and preparation method (slow precipitation method $\mathrm{v}$. rapid precipitation or $\mathrm{BiPO}_{4}$ method v. $\mathrm{Ag}_{3} \mathrm{PO}_{4}$ method), as pointed out by several workers (O'Neil et al. 1994; Vennemann et al. 2002; Lécuyer 2004). A value of $22.5 \%$ was suggested for $\mathrm{Ag}_{3} \mathrm{PO}_{4}$ analysis by Vennemann et al. (2002); however, recent papers by other authors as well as Vennemann suggest a value of $21.7 \%$ o (Lécuyer 2004; Lécuyer et al. 2007; Halas et al. 2011; Vennemann 2012). In order to make values comparable to the most recently accepted NIST $120 \mathrm{c}$ values, we subtracted $0.8 \%$ from all samples (our average NIST-120c value $(22.5 \%$ ) minus the currently accepted value of $21.7 \%$ ).

Siderite samples from the PCF were analysed for O-isotopic composition. Samples were thinsectioned for petrographic analysis and facing billets were used to sample pedogenic carbonates. Approximately $60-180 \mu \mathrm{g}$ of siderite from two levels of the PCF were micromilled and vacuumroasted at $200{ }^{\circ} \mathrm{C}$ to remove volatiles. All samples were then analysed by reaction with $100 \% \mathrm{H}_{3} \mathrm{PO}_{4}$ at $75^{\circ} \mathrm{C}$ and using the siderite-acid fractionation factor from Carothers et al. (1988) using a Kiel III carbonate reaction device interfaced to the inlet of a ThermoFinnigan MAT 253 dual inlet mass spectrometer. Siderite isotope data are reported relative to V-PDB. Precision was monitored through the daily analysis of NBS-18 and NBS-19 and was better than $0.10 \%$ for both $\delta^{13} \mathrm{C}$ and $\delta^{18} \mathrm{O}$.

Dinosaur ingested water was estimated using modified biological parameters for herbivorous birds, as presented by Kohn (1996). Kohn (1996) creates a mass balance equation accounting for input $\mathrm{O}$ moles and isotopic composition and output $\mathrm{O}$ moles, and modifies each for various animal physiologies. For herbivorous dinosaurs, the Kohn (1996) bird equation was modified to account for a sustained body temperature of $37^{\circ} \mathrm{C}$, v. the $38^{\circ} \mathrm{C}$ suggested by Amiot et al. (2006), a much larger body size (c. $200 \mathrm{~kg} \mathrm{v} .0 .15 \mathrm{~kg}$ for herbivorous birds in the Kohn model), which alters the food input requirements and respiratory $\mathrm{O}_{2}$ requirements as well as output of $\mathrm{O}$ moles, slightly lower digestibility for food (from 0.9 to 0.7 - coniferous forest food v. deciduous leaves), and equal amounts of water loss from skin and mouth (see Supplementary Material for comparison to Kohn 1996). An additional correction to the equation was made because the theoretical model was generated with data generated by converting animal phosphate to $\mathrm{BiPO}_{4}$. Oxygen isotopic compositions generated via conversion to $\mathrm{BiPO}_{4}$ analysis have been shown to be $c$. $1.0 \%$ lower than apatite conversion to 
$\mathrm{Ag}_{3} \mathrm{PO}_{4}$ (O’Neil 1994; Chenery et al. 2010). As such, the phosphate-body water fractionation of Kohn (1996) was altered from 17.5 to 18.5 (see Supplementary Material), resulting in the following equation for ingested water by herbivorous birds:

$$
\delta^{18} \mathrm{O}_{\mathrm{w}}=1.41 \delta^{18} \mathrm{O}_{\mathrm{p}}+20.1 h-49.69
$$

This modified herbivorous bird equation was then altered for increased input of $\mathrm{O}$ from protein and fat (Kohn 1996), resulting in the following equation for water ingested by carnivorous dinosaurs:

$$
\delta^{18} \mathrm{O}_{\mathrm{w}}=1.43 \delta^{18} \mathrm{O}_{\mathrm{p}}+7.3 h-40.69
$$

Humidity was estimated using an empirically derived data set - the model for the AptianAlbian from Suarez et al. (2011). In modelling water $\delta^{18} \mathrm{O}$-palaeo-latitudinal gradients as calculated from $2^{\circ} \mathrm{S}-75^{\circ} \mathrm{N}$ using Albian pedogenic carbonates, a modelled humidity of $c$. $77.5 \%$ was attained using a zonal MAT estimated from leaf physiognomy for the underlying Nanushuk Formation palaeo-latitude at $75^{\circ} \mathrm{N}$ with a MAT of $11.7^{\circ} \mathrm{C}$ (Wolfe \& Upchurch 1987; Spicer \& Corfield 1992). The MAT for the PCF is $6.3{ }^{\circ} \mathrm{C}$ at a palaeo-latitude of $c .82$ to $95^{\circ} \mathrm{N}$ (Spicer \& Parrish 1990; Spicer \& Herman 2010). Although this is lower than the MAT and palaeo-latitude during the Aptian-Albian, it is the best estimate available as no $\delta^{18} \mathrm{O}$-palaeo-latitudinal gradients have been developed for the CampanianMaastrichthian.

The isotopic composition of siderite converted to V-SMOW was used to calculate the water from which it precipitated. The temperature-dependent fractionation factor determined by Carothers et al. (1988) was used to calculate the isotopic composition of meteoric water:

$$
\begin{gathered}
1000 \ln \alpha=3.13 \times\left(10^{6} / T^{2}\right)-3.5 \\
\delta^{18} \mathrm{O}_{\mathrm{w}}-\mathrm{V}-\mathrm{SMOW}=\left(\left(\delta^{18} \mathrm{O}_{\text {sid }}+1000\right) / \delta\right)-1000
\end{gathered}
$$

Water was calculated at minimum, average and maximum temperatures of $-2{ }^{\circ} \mathrm{C}, 6.3^{\circ} \mathrm{C}$ and $14.5^{\circ} \mathrm{C}$, respectively (Spicer \& Herman 2010).

\section{Results}

The isotopic composition of dinosaurian phosphate (Table 1, Fig. 2a) ranges from a minimum of $3.9 \%$ V-SMOW for hadrosaurid teeth from Pediomys Point to a maximum of $10.2 \%$ for Troodon at Liscomb Bonebed and from a tyrannosaurid also from Liscomb Bonebed (10.2\%o). Data from the three sites were supplemented with data from large theropod teeth from Fricke \& Rogers (2000) $(9.4 \% o)$ and from analysis of a tyrannosaur tooth that was found as float along the Colville River $(8.1 \%$ ). The isotopic compositions of the siderite range between $-14.86 \%$ and $-16.21 \%$ V-PDB and are summarized in Table 2 and Figure $2 \mathrm{~b}$.

There are several trends that can be observed in the phosphate and siderite data, including the following.

- The isotopic compositions of siderite from the two levels are not significantly different from one other.

- The isotopic composition of carnivores tends to be more enriched than that of the herbivorous dinosaurs at each site, including the float Colville River tyrannosaurid tooth and the large theropod tooth from Fricke \& Rogers (2000), except when compared to ceratopsians at KikakTegoseak.

- Pediomys Point non-ceratopsian remains are lighter in isotopic composition than remains from Kikak-Tegoseak and Liscomb Bonebed.

- Liscomb Bonebed remains are heavier in isotopic composition than Kikak-Tegoseak and Pediomys Point remains.

The isotopic composition of water from siderite depends on the temperature at which it precipitated (Table 3, Fig. 3). At a minimum temperature (cold month mean) of $-2{ }^{\circ} \mathrm{C}$ (Spicer \& Herman 2010), water values ranged from $-24.66 \%$ V-SMOW to $-23.33 \%$ V-SMOW. At a maximum temperature (warm month mean) of $14.5{ }^{\circ} \mathrm{C}$ (Spicer \& Herman 2010) they ranged from $-20.03 \%$ to $-18.68 \%$, and at an average temperature of $6.3{ }^{\circ} \mathrm{C}$ they ranged from $-22.23 \%$ o to $-20.89 \%$.

The isotopic composition of ingested water for the different dinosaurs was similar to that of siderite (Table 3, Fig. 4). The values for Pachyrhinosaurus ranged from $-25.9 \%$ at Kikak-Tegoseak to $-23.4 \%$, also at Kikak-Tegoseak. The isotopic composition of non-ceratopsian herbivores (Edmontosaurus and hypsilophodontids) ranges between $-28.7 \%$ at Pediomys Point to $-22.8 \%$ o at Liscomb Bonebed. In comparison, the isotopic composition of carnivores ranged from a minimum of $-26.1 \%$ from a large theropod tooth from Kikak-Tegoseak to $-20.4 \%$ for a Troodon tooth at Liscomb Bonebed. The float Tyrannosaurid tooth from the Colville River averaged $-23.4 \%$, and the large theropod tooth analysed by Fricke \& Rogers (2000) averaged $-21.7 \%$.

There are several apparent trends in the calculated water values.

- The range for meteoric water calculated for siderite from -2 to $14.5{ }^{\circ} \mathrm{C}$ overlaps the range for water values calculated from dinosaurs, at minimum and average temperatures. 


$$
\text { C. A. SUAREZ ET AL. }
$$

Table 1. $\delta^{18} O_{p}$ of vertebrate remains relative to $\mathrm{V}$-SMOW

\begin{tabular}{|c|c|c|c|c|}
\hline Sample & Taxa & Locality & $\delta^{18} \mathrm{O}_{\mathrm{p}} \mathrm{V}-\mathrm{SMOW}$ & Laboratory \\
\hline DMNH-22881-a & Edmontosaurus & Liscomb & 8.0 & UCSC \\
\hline$-b c$ & & & 7.0 & KPESIL \\
\hline DMNH-21031-ab & Tyrannosauridae & Liscomb & 8.0 & KPESIL \\
\hline$-c$ & & & 8.2 & KPESIL \\
\hline$-d$ & & & 10.2 & UCSC \\
\hline DMNH-21047-a & Hadrosauridae & Liscomb & 8.6 & UCSC \\
\hline$-\mathrm{b}$ & & & 7.7 & UCSC \\
\hline$-c$ & & & 7.6 & UCSC \\
\hline$-d$ & & & 6.9 & UCSC \\
\hline$-\mathrm{e}$ & & & 7.5 & UCSC \\
\hline DMNH-22336b & Troodon formosus & Liscomb & 7.5 & KPESIL \\
\hline$-\mathrm{c}$ & & & 10.2 & KPESIL \\
\hline DMNH-22478-ab & Tyrannosauridae & Liscomb & 7.9 & KPESIL \\
\hline$-\mathrm{c}$ & & & 7.9 & KPESIL \\
\hline DMNH-22846-1 & Hadrosauridae & Pediomys & 4.1 & KPESIL \\
\hline$-\mathrm{b}$ & & & 3.9 & KPESIL \\
\hline DMNH-22846-2 & & & 3.9 & KPESIL \\
\hline$-b$ & & & 4.1 & KPESIL \\
\hline DMNH-22846-3 & & & 3.9 & KPESIL \\
\hline$-\mathrm{b}$ & & & 4.2 & KPESIL \\
\hline DMNH-22840-ac & Hypsilophodontidae & Pediomys Point & 6.9 & KPESIL \\
\hline$-\mathrm{b}$ & & & 6.2 & KPESIL \\
\hline$-d$ & & & 7.1 & KPESIL \\
\hline DMNH-22842-ab & Dromaeosauridae & Pediomys Point & 7.3 & KPESIL \\
\hline$-\mathrm{d}$ & & & 7.7 & KPESIL \\
\hline$-\mathrm{e}$ & & & 7.9 & KPESIL \\
\hline DMNH-22841b & Hypsilophodontidae & Pediomys Point & 6.6 & KPESIL \\
\hline DMNH-22532b & Pachyrhinosaurus & Pediomys Point & 6.9 & KPESIL \\
\hline DMNH-22493-a & Pachyrhinosaurus & Kikak-Tegoseak & 7.5 & UCSC \\
\hline$-\mathrm{b}$ & & & 7.3 & UCSC \\
\hline$-c$ & & & 7.6 & UCSC \\
\hline$-d$ & & & 6.6 & UCSC \\
\hline$-\mathrm{e}$ & & & 7.3 & UCSC \\
\hline DMNH-22484-a & Ornithischian & Kikak-Tegoseak & 6.1 & UCSC \\
\hline$-\mathrm{b}$ & & & 5.5 & UCSC \\
\hline$-\mathrm{c}$ & & & 5.5 & UCSC \\
\hline DMNH-22482-a & Pachyrhinosaurus & Kikak-Tegoseak & 5.9 & UCSC \\
\hline$-b$ & & & 7.0 & UCSC \\
\hline$-c$ & & & 6.6 & UCSC \\
\hline$-d$ & & & 6.7 & UCSC \\
\hline$-\mathrm{e}$ & & & 6.5 & UCSC \\
\hline DMNH-22150-a & Pachyrhinosaurus & Kikak-Tegoseak & 6.7 & UCSC \\
\hline$-\mathrm{b}$ & & & 6.3 & UCSC \\
\hline$-c$ & & & 6.1 & UCSC \\
\hline DMNH-22379-a & Theropod & Kikak-Tegoseak & 6.3 & KPESIL \\
\hline$-b$ & & & 8.1 & UCSC \\
\hline$-\mathrm{c}$ & & & 6.4 & KPESIL \\
\hline$-d$ & & & 6.4 & KPESIL \\
\hline$-\mathrm{e}$ & & & 6.4 & KPESIL \\
\hline DMNH-22200-a & Tyrannosauridae & Colville River (float) & 8.2 & UCSC \\
\hline$-b$ & & & 8.1 & UCSC \\
\hline$-c$ & & & 8.0 & UCSC \\
\hline$-d$ & & & 8.5 & UCSC \\
\hline$-\mathrm{e}$ & & & 7.8 & UCSC \\
\hline Theropod-1 & Large theropod & Fricke \& Rogers (2000) & 9.4 & KPESIL \\
\hline Theropod-2 & Large theropod & Fricke \& Rogers (2000) & 9.0 & KPESIL \\
\hline Theropod-3 & Large theropod & Fricke \& Rogers (2000) & 9.6 & KPESIL \\
\hline Theropod-4 & Large theropod & Fricke \& Rogers (2000) & 9.4 & KPESIL \\
\hline
\end{tabular}



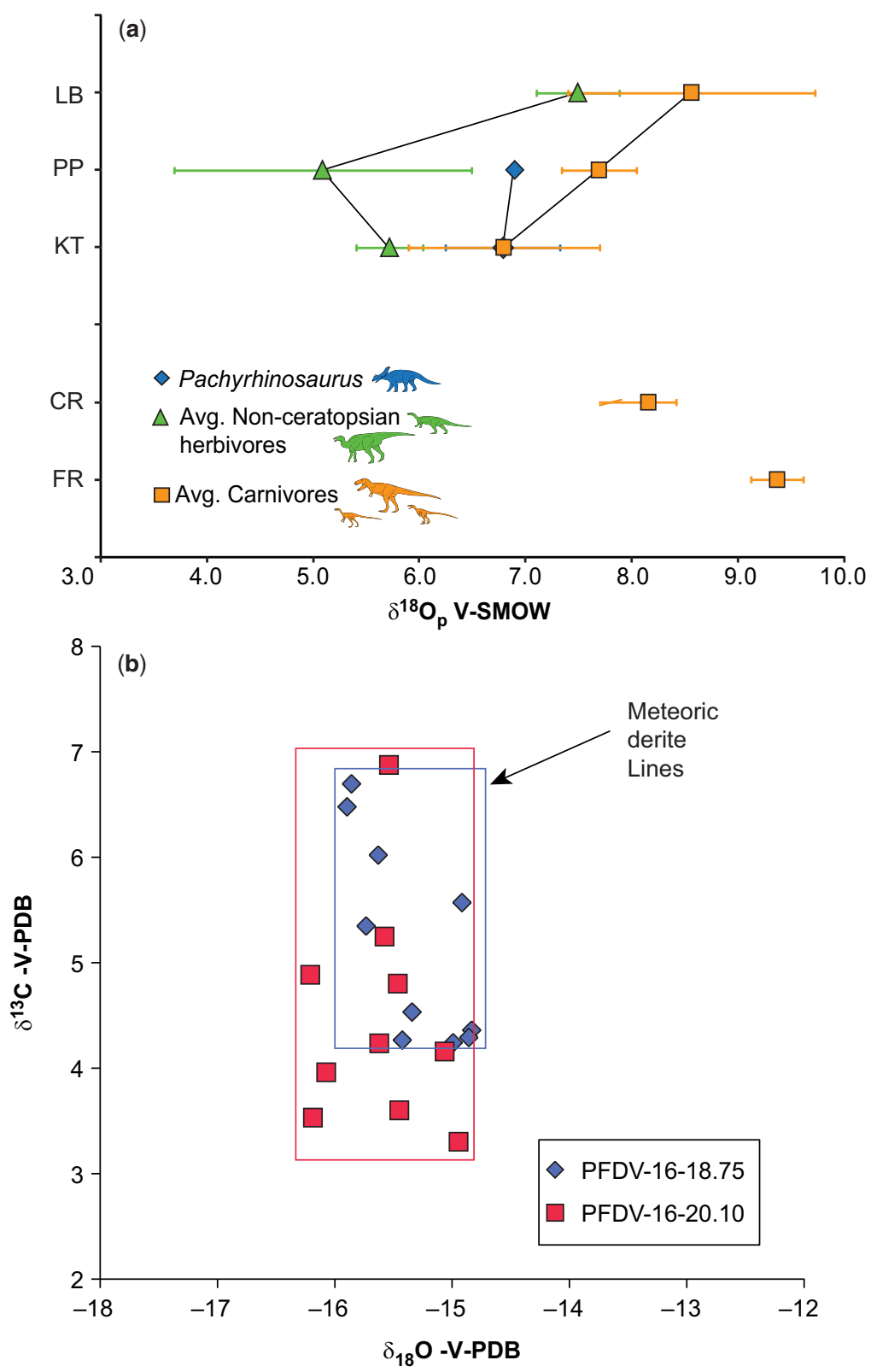

Fig. 2. Results of isotopic analysis. (a) O-isotopic composition of phosphate relative to V-SMOW. Sites are organized stratigraphically and are connected by lines. The Colville River tyrannosaurid tooth (CR) and the theropod teeth from the study of Fricke \& Rogers (2000) (FR) have unknown stratigraphic affiliation and so are not connected to sites whose stratigraphic relationship is known. (b) $\mathrm{C}$ - and $\mathrm{O}$-isotope cross-plot relative to V-PDB of siderite from the section PFDV-16, at $18.75 \mathrm{~m}$ and $20.10 \mathrm{~m}$ above the lower datum. Boxes define meteoric siderite lines characterized by $\delta^{13} \mathrm{C}$ variability greater than $\delta^{18} \mathrm{O}$ variability. LB, Liscomb Bonebed; PP, Pediomys Point; KT, Kikak-Tegoseak; CR, Colville River; FR, Fricke \& Rogers (2000). Error bars, one standard deviation.

- Water ingested by most carnivores tends to be more enriched in ${ }^{18} \mathrm{O}$ than for herbivorous dinosaurs.
- Water ingested by Pachyrhinosaurus is more enriched in ${ }^{18} \mathrm{O}$ than for other herbivorous dinosaurs. 


$$
\text { C. A. SUAREZ ET AL. }
$$

Table 2. Oxygen-isotopic composition of siderite relative to $\mathrm{V}$-SMOW

\begin{tabular}{lcccc}
\hline Sample & Level & $\begin{array}{c}\delta^{18} \mathrm{O}_{\text {sid }} \\
(\% \text {-VSMOW })\end{array}$ & Average & $1 \sigma$ \\
\hline PFDV-16-18.75 c & 18.75 & -14.86 & -15.40 & 0.43 \\
PFDV-16-18.75 d & 18.75 & -15.63 & \\
PFDV-16-18.75 e & 18.75 & -15.86 & \\
PFDV-16-18.75 f & 18.75 & -14.92 & \\
PFDV-16-18.75 g & 18.75 & -15.34 & \\
PFDV-16-18.75 h & 18.75 & -14.99 & \\
PFDV-16-18.75 i & 18.75 & -15.89 & \\
PFDV-16-18.75 j & 18.75 & -15.73 & \\
PFDV-16-20.1 a & 20.10 & -15.54 & \\
PFDV-16-20.1 b & 20.10 & -15.58 & \\
PFDV-16-20.1 c & 20.10 & -15.45 & \\
PFDV-16-20.1 d & 20.10 & -14.94 & \\
PFDV-16-20.1 e & 20.10 & -15.46 & \\
PFDV-16-20.1 f & 20.10 & -15.06 & \\
PFDV-16-20.1 g & 20.10 & -16.18 & \\
PFDV-16-20.1 h & 20.10 & -16.21 & \\
PFDV-16-20.1 i & 20.10 & -16.07 & \\
PFDV-16-20.1 j & 20.10 & -15.62 & \\
\hline
\end{tabular}

- Liscomb Bonebed records have the highest $\delta^{18} \mathrm{O}_{\mathrm{w}}$ values.

\section{Discussion}

We analysed the more diagenetically resistant bioapatite, enamel. Enamel has larger crystal sizes than bone apatite as well as decreased organic content $(<10 \%)$, resulting in a low surface area available for isotopic exchange (Kolodny et al. 1996; Glimcher 2006). Inorganic isotopic exchange tends to occur to bone carbonate (Zazzo et al. 2004) rather than phosphate. The phosphate molecule is significantly more resistant to diagenesis than the easily exchangeable carbonate molecule (Kolodny et al. 1996; Sharp et al. 2000). However, some researchers have demonstrated isotopic exchange via microbial alteration to phosphate (Blake et al. 1998; Zazzo et al. 2004). Other studies have used the $c .9 \%$ offset between $\delta^{18} \mathrm{O}_{\mathrm{p}}$ and $\delta^{18} \mathrm{O}_{\text {egg CO3 }}$ when precipitated at equilibrium from the same body water to suggest the primary O-isotopic composition of phosphate (Iacumin et al. 1996; Bojar et al. 2010). The separation of $\delta^{18} \mathrm{O}$ values of vertebrate remains along physiological and dietary lines (e.g. carnivores v. herbivores) has also been used to indicate the preservation of original biogenic signals (Lécuyer et al. 2003; Fricke et al. 2008; Amiot et al. 2009). For example, Lécuyer et al. (2003) analysed a wide diversity of Late Cretaceous taxa from the Laño locality of northern Spain and reported $\delta^{18} \mathrm{O}_{\mathrm{p}}$ values for crocodile teeth (19.2\%o), an Iguanodon tooth (19.3\%o), an Ankylosaurus tooth $(19.3 \%$ o), a fish scale $(19.7 \%$ ) , a turtle shell (19.5\%o), alligator teeth (19.5\%), a Titanosaurus tooth $(19.4 \% 0)$, a theropod tooth $(19.1 \%$ ) , a shark tooth $(19.4 \%$ ) and a ray tooth $(18.7 \%$ ) with no more than $1.0 \%$ difference between taxa, suggesting poor preservation of the original biological information. There are clear differences in phosphate values along dietary and physiological lines for the PCF data. For example, at all sites, theropod $\delta^{18} \mathrm{O}_{\mathrm{p}}$ is significantly greater than in herbivores, with the exception of Pachyrhinosaurus at KikakTegoseak (Fig. 2, Table 1). Pachyrhinosaurus tends to be significantly enriched in ${ }^{18} \mathrm{O}$ relative to other herbivores both at Pediomys Point and Kikak-Tegoseak Quarry (Fig. 2, Table 1).

Siderite values also preserve original material. Thin-section analysis revealed that the analysed materials were microcrystalline siderites (Fig. 5). Additionally, the cross-plots of $\mathrm{C}$ and $\mathrm{O}$ (Fig. 2b) reveal a meteoric siderite line characterized by an $\mathrm{O}$-isotopic variation that is less than the $\mathrm{C}$-isotopic variation. This is typical of original soil carbonates (Ludvigson et al. 1998; Suarez et al. 2010).

\section{PCF palaeohydrology}

The calculated stable isotopic compositions of $\delta^{18} \mathrm{O}_{\mathrm{w}}$ from dinosaurs and pedogenic siderite can be used to describe the regional palaeohydrology of the PCF (Figs $3 \& 4$ ). First, when compared broadly to siderite, the calculated dinosaur-ingested water isotopic compositions are similar to those calculated from siderite, suggesting the majority of water consumed by dinosaurs was in the same compositional range as meteoric water estimated 


\section{ARCTIC PALAEOHYDROLOGY OF THE CRETACEOUS}

Table 3. Calculated $\delta^{18} \mathrm{O}$ of meteoric water from siderite and $\delta^{18} \mathrm{O}$ ingested water from dinosaurs

\begin{tabular}{|c|c|c|c|c|c|}
\hline Sample & Taxa/material & Location & $\begin{array}{c}\text { Temperature } \\
\left({ }^{\circ} \mathrm{C}\right)\end{array}$ & $\delta^{18} \mathrm{O}_{\mathrm{w}}$ & $1 \sigma$ \\
\hline PFDV-16-18.75 & Siderite & $18.75 \mathrm{~m}$ & -2 & -23.86 & 0.43 \\
\hline PFDV-16-18.75 & Siderite & $18.75 \mathrm{~m}$ & 6.3 & -21.43 & 0.43 \\
\hline PFDV-16-18.75 & Siderite & $18.75 \mathrm{~m}$ & 14.5 & -19.22 & 0.43 \\
\hline PFDV-16-20.10 & Siderite & $20.10 \mathrm{~m}$ & -2 & -24.07 & 0.43 \\
\hline PFDV-16-20.10 & Siderite & $20.10 \mathrm{~m}$ & 6.3 & -21.64 & 0.43 \\
\hline PFDV-16-20.10 & Siderite & $20.10 \mathrm{~m}$ & 14.5 & -19.43 & 0.43 \\
\hline DMNH-22881 & Edmontosaurus & Liscomb & 37 & -23.6 & 1.1 \\
\hline DMNH-21047 & Hadrosauridae & Liscomb & 37 & -23.6 & 0.4 \\
\hline DMNH-21031 & Tyrannosauridae & Liscomb & 37 & -22.5 & 1.8 \\
\hline DMNH-22478 & Tyrannosauridae & Liscomb & 37 & -23.8 & 0.1 \\
\hline DMNH-22336 & Troodon & Liscomb & 37 & -22.4 & 2.8 \\
\hline Avg carnivores & & Liscomb & 37 & -22.8 & 1.7 \\
\hline $\begin{array}{l}\text { Avg non-ceratopsian } \\
\text { herbivores }\end{array}$ & & Liscomb & 37 & -23.6 & 0.6 \\
\hline DMNH-22846-1 & Hadrosauridae & Pediomys Point & 37 & -28.5 & 0.1 \\
\hline DMNH-22846-2 & Hadrosauridae & Pediomys Point & 37 & -28.6 & 0.2 \\
\hline DMNH-22846-3 & Hadrosauridae & Pediomys Point & 37 & -28.5 & 0.4 \\
\hline DMNH-22840 & Hypsilophodontidae & Pediomys Point & 37 & -25.0 & 0.5 \\
\hline DMNH-22841 & Hypsilophodontidae & Pediomys Point & 37 & -24.9 & 0.0 \\
\hline DMNH-22532 & Pachyrhinosaurus & Pediomys Point & 37 & -24.4 & 0.0 \\
\hline DMNH-22842 & Dromaeosauridae & Pediomys Point & 37 & -24.1 & 0.5 \\
\hline Avg. carnivores & & Pediomys Point & 37 & -24.1 & 0.5 \\
\hline $\begin{array}{l}\text { Avg. non-ceratopsian } \\
\text { herbivores }\end{array}$ & & Pediomys Point & 37 & -27.1 & 2.0 \\
\hline Avg. ceratopsian & & Pediomys Point & 37 & -24.4 & 0.0 \\
\hline DMNH-22484 & Ornithischian & Kikak-Tegoseak & 37 & -26.1 & 0.4 \\
\hline DMNH-22493 & Pachyrhinosaurus & Kikak-Tegoseak & 37 & -23.9 & 0.6 \\
\hline DMNH-22482 & Pachyrhinosaurus & Kikak-Tegoseak & 37 & -24.9 & 0.6 \\
\hline DMNH-22150 & Pachyrhinosaurus & Kikak-Tegoseak & 37 & -25.2 & 0.5 \\
\hline DMNH-22379 & Large theropod & Kikak-Tegoseak & 37 & -25.4 & 1.1 \\
\hline Avg. carnivores & & Kikak-Tegoseak & 37 & -25.4 & 1.1 \\
\hline $\begin{array}{l}\text { Avg. non-ceratopsian } \\
\text { herbivores }\end{array}$ & & Kikak-Tegoseak & 37 & -26.1 & 0.4 \\
\hline Avg. ceratopsian & & Kikak-Tegoseak & 37 & -22.8 & 0.8 \\
\hline DMNH-22200 & Tyrannosauridae & Colville River & 37 & -23.4 & 0.4 \\
\hline Theropod-1 & Large theropod & F\&R 2000 & 37 & -21.6 & \\
\hline Theropod-2 & Large theropod & & 37 & -22.2 & \\
\hline Theropod-3 & Large theropod & & 37 & -21.3 & \\
\hline Theropod-4 & Large theropod & & 37 & -21.6 & \\
\hline Avg. large theropod & & & 37 & -21.7 & 0.4 \\
\hline
\end{tabular}

by siderite (Fig. 4). Small variations within the dinosaur-ingested water values can help to tease out regional differences within the PCF. For example, non-ceratopsian herbivores document $\delta^{18} \mathrm{O}_{\mathrm{w}}$ values as low as $-28.7 \%$, up to $9.5 \%$ o lower than the $\delta^{18} \mathrm{O}_{\mathrm{w}}$ calculated from siderite at maximum temperatures from $18.75 \mathrm{~m}$ in PFDV-16 (Figs 3 $\& 4)$. This value may be the result of orographically depleted water or snowmelt water from the Brooks Range. It is well documented that local rivers are more depleted in ${ }^{18} \mathrm{O}$ than local meteoric water due to the catchment effect (Dettman \& Lohmann 2000; Dutton et al. 2005; Suarez et al.
2011). Assuming a river water isotope gradient (lapse rate) of $-4.2 \% / \mathrm{km}$ decrease in $\delta^{18} \mathrm{O}$ (Dutton et al. 2005) and a meteoric water lapse rate of $2.8 \% \circ / \mathrm{km}$, where the isotopic composition of meteoric water is $c$. $-19.2 \%$, that of river water is $-20.6 \%$. If the minimum $\delta^{18} \mathrm{O}_{\mathrm{w}}$ calculated from non-ceratopsian enamel is $-28.7 \%$, resulting in a $8.1 \%$ decrease in $\delta^{18} \mathrm{O}$, non-ceratopsian dinosaurs would have consumed river water sourced from as much as $1.9 \mathrm{~km}$ of elevation higher than the elevation at which siderite formed. This is a reasonable estimate for the area as the Brooks Range palaeo-elevation is placed conservatively 


\section{A. SUAREZ ET AL.}

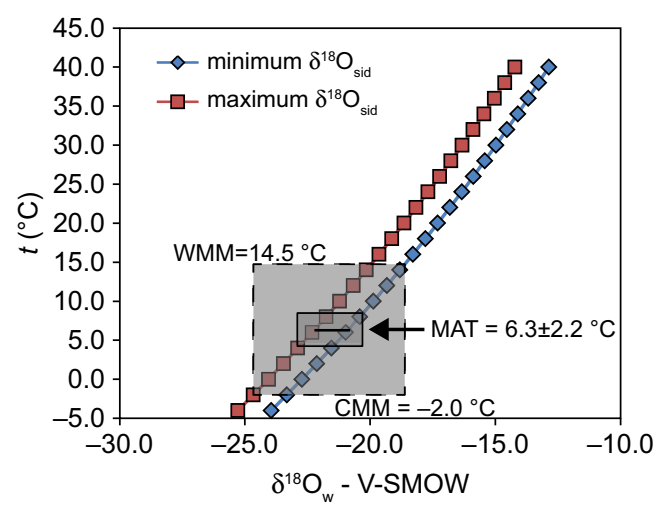

Fig. 3. Isotopic composition of meteoric water derived from Prince Creek Formation siderites based on the temperature-dependent fractionation equation of Carothers et al. (1988). The two lines represent water values from the maximum (red squares) and minimum (blue diamonds) siderite $\delta^{18} \mathrm{O}$ values plotted at various temperatures. The solid box represents the range of water compositions at a MAT of $6.3{ }^{\circ} \mathrm{C}$ (line) $\pm 2.2{ }^{\circ} \mathrm{C}$ (solid box) and the dashed box represents ranges of water isotopic compositions at a warm month mean (WMM) of $14.5^{\circ} \mathrm{C}$ and cold month mean (CMM) of $-2{ }^{\circ} \mathrm{C}$ based on temperatures determined from CLAMP analysis of Spicer \& Herman (2010).

at $1.5 \mathrm{~km}$ (Spicer 2003) and as high as $4 \mathrm{~km}$ (Vogl et al. 2002; Poulsen et al. 2007). Pediomys Point documents the lightest $\delta^{18} \mathrm{O}_{\mathrm{w}}$ of the three sites, despite the fact that Kikak-Tegoseak was closest to the Brooks Range. One might expect that sites closest to the mountains would capture the most ${ }^{18} \mathrm{O}$-depleted water compositions. However, the light $\delta^{18} \mathrm{O}_{\mathrm{w}}$ documented at Pediomys Point might result from a taphonomic bias. Remains were deposited in a coarse-grained lag at the base of a fine- to medium-grained sandstone with cross-bedding and ripples, and although the presence of jarosite and brackish-water clams suggest possible marine influences found in the deposit, it is possible that the remains came from much closer to the mountains, where the animals might have consumed much lighter water, and then their remains were transported downstream to the coastal plain.

Liscomb Bonebed, on the other hand, documents the highest $\delta^{18} \mathrm{O}_{\mathrm{w}}$ (maximum of $-22.4 \%$ ). It is also the site that is furthest to the north. Palaeogeographic reconstruction (Fig. 1c) suggests that it would have been very close to the coast and the presence of jarosite in the overlying beds suggest the influence of marine or mixed waters (Flaig 2010; Flaig et al. 2011). The combination of siderite and dinosaurian data suggest that the PCF regional palaeohydrology consisted of meteoric water that averaged c. $-21 \%$ with an orographically influenced $\delta^{18} \mathrm{O}_{\mathrm{w}}$ composition of $c$. $-28 \%$ and near-coastal precipitation of $c .-19 \%$.

\section{PCF dinosaur palaeoecology}

Relative to one another, the different taxa from the PCF show some unique groupings. The most evident is the ${ }^{18} \mathrm{O}$-enriched nature of carnivore phosphate and calculated ingested water (Figs $2 b$ $\& 4)$. Theoretical modelling and some observations suggest carnivores should be depleted relative to herbivores due to herbivore consumption of evaporatively ${ }^{18}$ O-enriched plant leaves (Kohn 1996; Levin et al. 2006). However, PCF carnivores are more enriched than the herbivores. Without additional modern data it is difficult to explain this offset; however, carnivore data from the Pleistocene Natural Trap Cave, Wyoming, USA, also show an ${ }^{18} \mathrm{O}$-enriched carnivore O-isotopic composition relative to herbivores (McKay 2008). McKay (2008) explains that this enrichment may be due to changes in the proportion of drinking water relative to food water with high protein content, high vapour output or other unknown physiological differences not accounted for in the carnivorous models of Kohn (1996). Additional error for the estimated carnivorous bird equation used for theropods, such as whether or not they excreted urea or urinated, may also add to the calculated enrichment of carnivorous dinosaur phosphate. Pachyrhinosaurus teeth tend to be more enriched relative to other herbivorous dinosaurs such as Edmontosaurus and unidentified hypsilophodonts. This is probably due to differences in drinking water source and/or consumed food water. Non-ceratopsians that have lower $\delta{ }^{18} \mathrm{O}_{\mathrm{p}}$ values relative to ceratopsians (Pachyrhinosaurus) may have relied heavily on the river water that drained the Brooks Range, which was ${ }^{18} \mathrm{O}$-depleted due to orographic effects (Dettman \& Lohmann 2000; Suarez et al. 2012). The ${ }^{18} \mathrm{O}$-depleted nature of non-ceratopsian teeth does not necessarily suggest migration to uplands, as has been relied on by other authors (e.g. Fricke et al. 2008, 2011). A more parsimonious explanation is that the rivers drained isotopically depleted water from higher in the catchment basin. Some authors have suggested PCF dinosaurs may have migrated to the coast during the dark winter season to consume aquatic plants such as seagrass (Brinkman et al. 1998; Gangloff \& Fiorillo 2010). The isotopic data reported here do not support this. Seagrass should have $\delta^{18} \mathrm{O}_{\mathrm{w}}$ values similar to sea water, which in the Cretaceous was $c$. $-1.2 \%$ o (Poulsen et al. 2007; Suarez et al. 2011). Pachyrhinosaurus have the highest $\delta^{18} \mathrm{O}_{\mathrm{p}}$ values relative to other herbivores. If Pachyrhinosaurus consumed seagrass for a significant portion of the year, their $\delta^{18} \mathrm{O}_{\mathrm{p}}$ and calculated $\delta^{18} \mathrm{O}_{\mathrm{w}}$ would be higher 


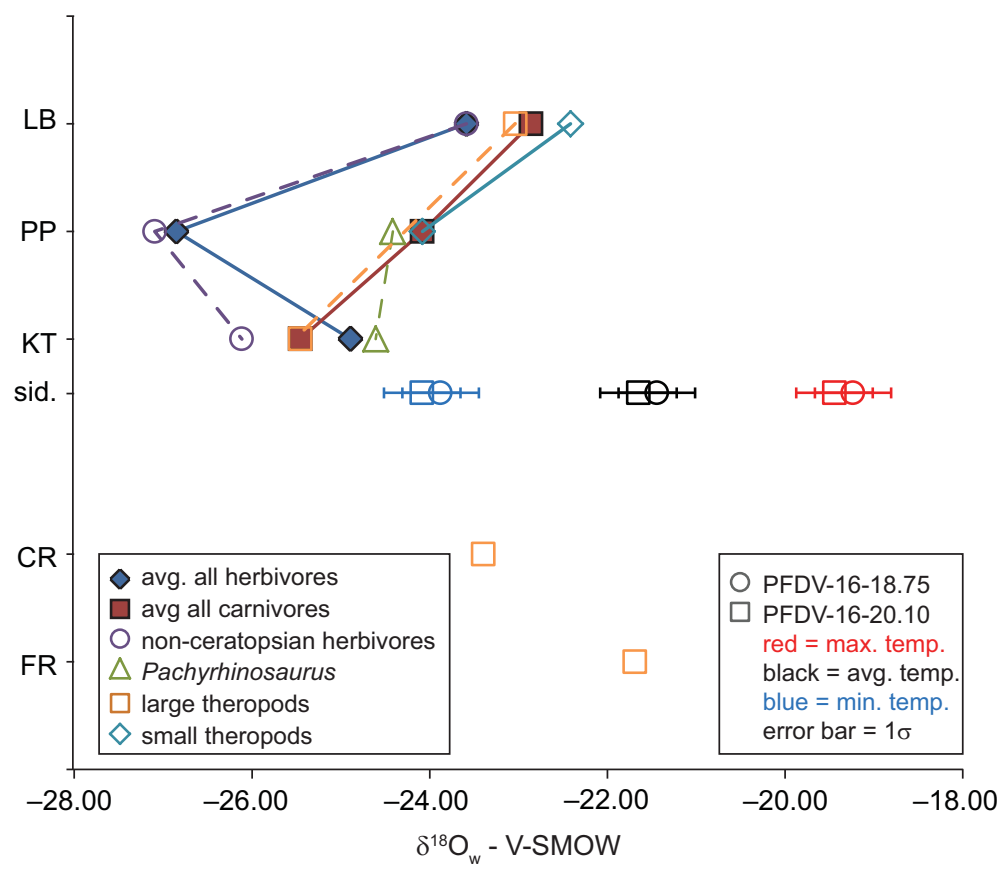

Fig. 4. Oxygen isotopic composition of PCF water relative to V-SMOW calculated from dinosaur tooth enamel and siderite at minimum (blue), MAT (black) and maximum (red) temperatures, as suggested by Spicer \& Herman (2010). Note that the range in water calculated from dinosaur tooth enamel encompasses the range of water values calculated from siderite. LB, Liscomb Bonebed; PP, Pediomys Point; KT, Kikak-Tegoseak; sid., siderite; CR, Colville River tyrannosaur; FR, Fricke \& Rogers (2000).

relative to meteoric water, calculated from the PCF. More probably, Pachyrhinosaurus may have foraged for food in the coniferous forests of the coastal floodplains away from riparian areas. Nonceratopsian herbivores may have foraged for food in the riparian areas where the $\delta^{18} \mathrm{O}$ of river water and $\delta^{18} \mathrm{O}$ of plant water offsets are minimal. Further analysis of a much larger data set as well as the addition of $\mathrm{C}$-isotopic composition analysis of tooth enamel may be helpful to clearly define PCF dinosaur palaeoecology.

\section{Arctic palaeoclimate in the Cretaceous}

The similarity of $\delta^{18} \mathrm{O}_{w}$ values calculated from enamel and siderite is an independent corroboration for the light $\delta^{18} \mathrm{O}$ of meteoric water at high latitudes documented by other authors (Ludvigson et al. 1998; Ufnar et al. 2002, 2004a, b; Suarez et al. 2011). The range in $\delta^{18} \mathrm{O}$ of dinosaur-ingested water suggests the orographically ${ }^{18} \mathrm{O}$-depleted endmember of snowmelt was $c$. $-28 \%$ o. Siderite values at MAT are much more restricted, ranging between $-21.23 \%$ and $-20.89 \%$, indicating they were not depleted by orographic processes as suggested by Poulsen et al. (2007). Additionally, when compared to the $\delta^{18} \mathrm{O}_{\mathrm{w}}$ values calculated from siderites of the underlying Nanushuk Formation $(-20.57 \%$ o to $-21.07 \%$ ), when the Arctic MAT was closer to $11{ }^{\circ} \mathrm{C}$ (Parrish \& Spicer 1988; Ufnar et al. 2004a; Suarez et al. 2011), values for the PCF are virtually identical $(-21.23 \%$ o to $-20.89 \%$ o) From the Albian-Cenomanian time (Nanushuk Formation) to the Campanian-Maastrichtian time (PCF), the formation of siderite went from a more proximal position relative to the Brooks Range to a more distal position (along the coastal plain). This distance should result in an increase in $\delta^{18} \mathrm{O}_{\mathrm{w}}$; however, there is a decrease. This decrease is not solely a result of formation at colder temperatures, because dinosaurs, which were thermoregulating to some degree (Amiot et al. 2006), document similar $\delta^{18} \mathrm{O}_{\mathrm{w}}$ values. We suggest that the low $\delta^{18} \mathrm{O}$ of meteoric water from the PCF was the result of increased rainout effects due to an intensified hydrological cycle that enhanced latent heat transport, as suggested for the Aptian-Albian by Ludvigson et al. (1998), Ufnar et al. (2004b) and Suarez et al. (2011). The increased latent heat transport may be due to a short-term global warming event (middle Maastrichtian event), as documented by several authors (Frank \& Arthur 


\section{A. SUAREZ ET AL.}
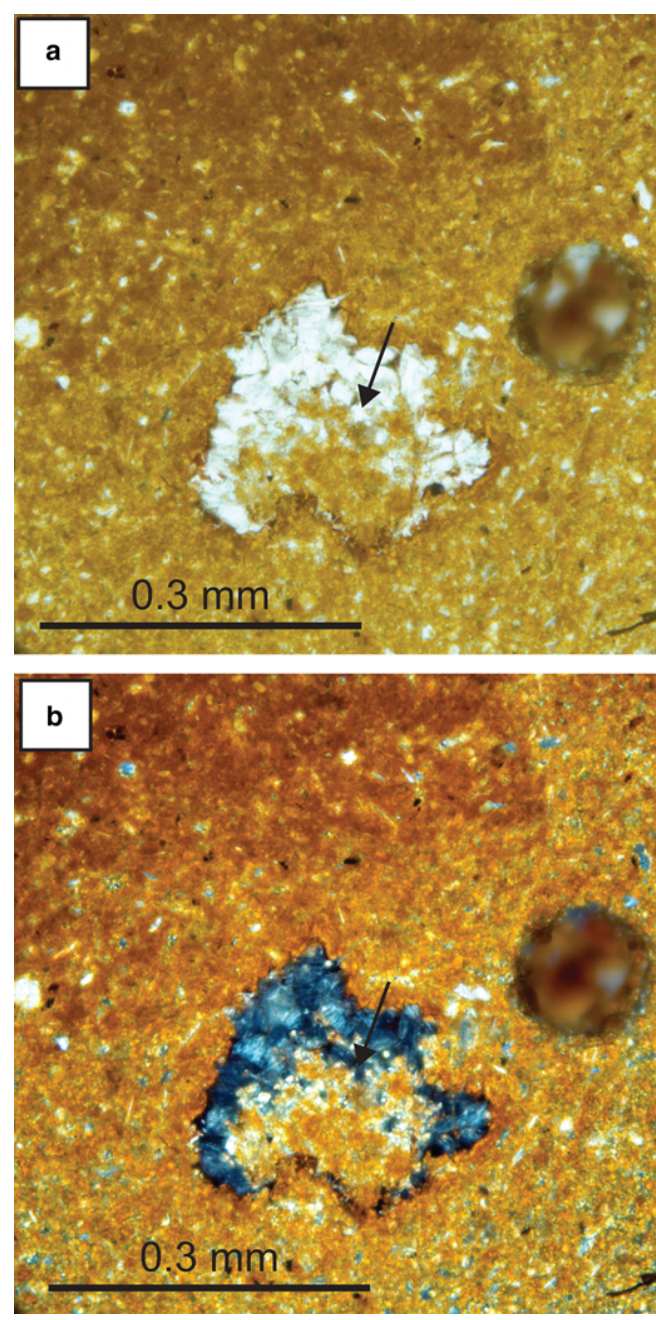

Fig. 5. Photomicrograph of microcrystalline siderite in (a) plain polarized light and (b) cross-polarized light. The arrow points to clusters of microcrystalline crystals of siderite contained within a zeolite-filled vug. Siderite is pervasive throughout the matrix.

1999; Keller 2001; Bralower et al. 2002; Nordt et al. 2003). The depleted nature of meteoric water (compared to the Nanushuk Formation) may also be due to the potential increase in palaeo-latitude from $c$. $70^{\circ}$ to $75^{\circ} \mathrm{N}$ during the Nanushuck Formation to $82^{\circ}$ to $85^{\circ} \mathrm{N}$ during the Maastrichtian (Parrish \& Spicer 1988; Spicer \& Herman 2010).

\section{Implications for modern Arctic climate}

This work serves as a case study of warm-period Arctic climate research. The increase in latent heat transport suggested by this and other workers (Ludvigson et al. 1998; Ufnar et al. 2004b; Suarez et al. 2011) suggests increased transfer of heat to the poles via the hydrological cycle. This has important implications for current polar warming and the Arctic amplification phenomenon documented by Graversen et al. (2008). Arctic amplification refers to the accelerated industrial-age warming at Arctic latitudes. Hypotheses for the cause of this warming focus on everything from snowice albedo decreases and changes in oceanicatmospheric circulation, to changes in cloud cover. The rapid feedbacks of Arctic amplification as well as significant warming at higher levels of the atmosphere suggest that atmospheric heat transport is an important cause of recent Arctic warming. These trends can be tracked with stable isotopic proxies, and palaeo-hydrological research of other warm Arctic worlds in Earth history may help provide answers to the causes of modern Arctic amplification.

Cretaceous warm worlds suggest an increase in rainout due to enhanced latent heat transport based on sediments containing extremely ${ }^{18} \mathrm{O}$-depleted meteoric water proxies at high latitudes, such as those seen in this study. However, other warm Arctic worlds such as that documented in the Paleocene-Eocene suggest an increase in $\delta^{18} \mathrm{O}$ and $\delta \mathrm{D}$ of meteoric water relative to modern-day Arctic meteoric water (Pagani et al. 2006; Jahren et al. 2009). This may be due to decreased meridional and/or vertical temperature gradients resulting in warmer polar temperatures. This decreased temperature gradient would decrease the fractionation due to rainout effects (Pagani et al. 2006). Alternatively, meteoric water transport may have been vastly different from today, originating somewhere other than the tropics (Jahren et al. 2009). Clearly, significant research endeavours with detailed proxy data and coupled modelling needs to be conducted in the future to understand the underlying factors that cause amplified Arctic warming and positive feedbacks associated with Arctic warming.

\section{Conclusions}

Stable isotopic analysis of terrestrial vertebrate phosphate is a valuable tool to elucidate regional palaeohydrology, which is not attainable exclusively by means of analysis of soil carbonates. However, it adds potential complications to interpretation (e.g. differences in migration v. multiple local water sources), although it may also offer insights into the range of local water reservoirs. For this study, the addition of vertebrate phosphate as a proxy material both validates the ${ }^{18} \mathrm{O}$-depleted nature of meteoric water in high latitudes (PCF as low as $c .-24 \% o$ ) and also adds additional information 
regarding the range in isotopic composition of the various water reservoirs found in the regional palaeohydrology of the PCF (i.e. Brooks Range runoff and coastal precipitation). For the PCF, snowmelt runoff was as high as $c$. $6 \%$ lower (or depleted) than in local meteoric water $(-22.23 \%$ to $-20.89 \%$ at a MAT of $6.3{ }^{\circ} \mathrm{C}$ ). Based on the isotopic composition of vertebrate phosphate from the Liscomb Bonebed, which was at a distal location relative to the orogenic belt and near the coast, nearshoreline precipitation was as heavy as $-20.4 \%$.

Of all the dinosaurs, carnivores tend to record the highest $\delta^{18} \mathrm{O}_{\mathrm{w}}$ values. This can be attributed to physiological fractionations not being accurately modelled in our equation (e.g. increased proportion of metabolic water as opposed to drinking surface water; urea excretion v. urination) or the consumption of food/water that was enriched relative to local meteoric water (Kohn 1996; McKay 2008). Relative to other herbivores, Pachyrhinosaurus is enriched in ${ }^{18} \mathrm{O}$, suggesting consumption of enriched food sources (e.g. plants outside riparian areas). There is no evidence of migration and consumption of shoreline plants as suggested by Brinkman et al. (1998) and Gangloff \& Fiorillo (2010). The depleted nature of non-ceratopsians may suggest water dependence and the consumption of isotopically depleted river water draining the Brooks Range, or the consumption of plants from riparian areas.

The overlap in the $\delta^{18} \mathrm{O}$ of dinosaur-ingested water and meteoric water from siderite corroborates ${ }^{18} \mathrm{O}$-depleted high-latitude precipitation in a warmer Arctic than today $\left(c .-19.0\right.$ at a MAT of $\left.-12{ }^{\circ} \mathrm{C}\right)$ (IAEA 1992). This depleted meteoric water was probably a result of increased rainout linked to an intensified hydrological cycle that increased latent heat transport to the poles (Ludvigson et al. 1998; Ufnar et al. 2004b; Suarez et al. 2011). This intensified hydrological cycle may have contributed to the amplified warming of Arctic temperatures, and may be analogous to modern observation of amplified Arctic temperatures relative to those that are modelled for the modern climate system (Graversen et al. 2008). An intensive research effort to study the palaeoclimate of the Arctic over geological time is needed to understand the unique climate dynamics of the Arctic and to understand what factors contribute to Arctic thermal variations.

We would like to acknowledge the technical and financial support of several institutions. The Barrow Arctic Science Consortium (BASC) and CH2M Hill (formerly Veco Polar Resources) provided logistical support for this project. Funding was provided by the National Science Foundation Office of Polar Programs (OPP 0424594 and OPP 0425636). The Arctic Management Unit of the Bureau of Land Management provided administrative support. The specimens were collected under BLM permit no. AA-86367. Additional financial support was provided by the Kansas Geological Survey. We acknowledge the very helpful reviews provided by $\mathrm{S}$. Halas and C. Lécuyer as well as A. Voica Bojar. We also thank M. Kohn for helpful discussions about the animal mass balance equations and standards use.

\section{References}

Amiot, R., Lécuyer, C., Buffetaut, E., Fluteau, F., Legendre, S. \& Martineau, F. 2004. Latitudinal temperature gradient during the Cretaceous Upper Campanian-Middle Maastrichtian: $\delta^{18} \mathrm{O}$ record of continental vertebrates. Earth and Planetary Science Letters, 226, 255-272.

Amiot, R., Lecuyer, C., Buffetaut, E., Escarguel, G., Fluteau, F. \& Martineau, F. 2006. Oxygen isotopes from biogenic apatites suggest widespread endothermy in Cretaceous dinosaurs. Earth Planetary Science Letters, 246, 41-54.

Amiot, R., Buffetaut, E., Lecuyer, C., Fernandez, V., Fourel, F., Martineau, F. \& Suteethorn, V. 2009. Oxygen isotope composition of continental vertebrate apatites from Mesozoic formations of Thailand; environmental and ecological significance. In: BUFFEtaut, E., Cuny, G., Le Loeuff, J. \& Suteethorn, V. (eds) Late Palaeozoic and Mesozoic Ecosystems in SE Asia. Geological Society, London, Special Publications, 315, 271-283.

Barrera, E. \& Savin, S. 1999. Evolution of late Campanian-Maastrichtian marine climates and oceans. In: Barrera, E. \& Johnson, C. (eds) Evolution of the Cretaceous Ocean-Climate System. Geological Society of America, Special Paper, 332, 245-282.

Barrick, R. E., Fisher, A. L. \& Showers, W. J. 1999. Oxygen isotopes from turtle bone: applications for terrestrial paleoclimates. Palaios, 14, 186-191.

Bassett, D., Macleod, K. G., Miller, J. F. \& EthingTON, R. L. 2007. Oxygen isotopic composition of biogenic phosphate and the temperature of Early Ordovician Seawater. Palaios, 22, 98-103.

Besse, J. \& Courtillot, V. 1991. Revised and synthetic apparent polar wander paths of the African, Eurasian, North American and Indian plates, and true polar wander since 200 Ma. Joumal of Geophysical Research, 96, 4029-4050.

Blake, R. E., O’Neil, J. R. \& Garcia, G. A. 1998. Effects of microbial activity on the $\delta^{18} \mathrm{O}$ of dissolved inorganic phosphate and textural feature of synthetic apatites. American Mineralogist, 83, 1516-1531.

BLAKEY, R. 2011. Paleogeography and geologic evolution of North America. World Wide Web Address: http:// www2.nau.edu/rcb7/nam.html

Bojar, A.-V., Csiki, Z. \& Grigorescu, D. 2010. Stable isotope distribution in Maastrichtian vertebrates and paleosols from the Hateg Basin, South Carpathians. Palaeogeography, Palaeoclimatology, Palaeoecology, 293, 329-342.

Bralower, T. J., Premoli Silva, I. \& Malone, M. J. 2002. New evidence for abrupt climate change in the Cretaceous and Paleogene: an Ocean Drilling Program expedition to Shatsky Rise, northwest Pacific. GSA Today, 12, 4-10. 


\section{A. SUAREZ ET AL.}

Breecker, D. O., Sharp, Z. D. \& McFadden, L. D. 2009. Seasonal bias in the formation and stable isotopic composition of pedogenic carbonate in modern soils from central New Mexico, USA. Geological Society of America Bulletin, 121, 630-640.

Brinkman, D. B., Ryan, M. J. \& Eberth, D. A. 1998. The paleogeographic and stratigraphic distribution of ceratopsids (Ornithischia) in the upper Judith River Group of western Canada. Palaios, 13, 160-169.

Carothers, W. W., Adami, L. H. \& Rosenbauer, R. J. 1988. Experimental oxygen isotope fractionation between siderite-water and phosphoric acid liberated $\mathrm{CO}_{2}$-siderite. Geochimica et Cosmochimica Acta, 52, 2445-2450.

Cerling, T. E. \& Quade, J. 1993. Stable carbon and oxygen isotopes in soil carbonates. In: SWART, P. K., Lohmann, K. C., McKenzie, J. A. \& Savin, S. (eds) Climate Change in Continental Isotopic Records. American Geophysical Union Geophysical Monograph, 78, 217-231.

Chenery, C., Müldnner, G., Evans, J., Eckardt, H. \& LEWIS, M. 2010. Strontium and stable isotope evidence for diet and mobility of Roman Gloucester, UK. Journal of Archaeological Science, 37, 150-163.

Clementz, M. T. \& КосH, P. L. 2001. Differentiating aquatic mammal habitat and foraging ecology with stable isotopes in tooth enamel. Oecologia, 129, 461-472.

Cojan, I., Renard, M. \& Emmanuel, L. 2003. Palaeoenvironmental reconstruction of dinosaur nesting sites based on a geochemical approach to eggshells and associated palaeosols (Maastrichtian, Provence Basin, France). Palaeogeography, Palaeoclimatology, Palaeoecology, 191, 111-138.

Conrad, J. E., McKee, E. H. \& Turrin, B. D. 1990. Age of tephra beds at the Ocean Point Dinosaur Locality, North Slope, Alaska, based on $\mathrm{K}-\mathrm{Ar}$ and ${ }^{40} \mathrm{Ar} /{ }^{39} \mathrm{Ar}$ analyses. United States Geological Survey Bulletin, 1990-C, 1-12.

Dettman, D. L. \& Lohmann, K. C. 2000. Oxygen isotope evidence from high altitude snow in the Laramide Rocky Mountains of North America during the later Cretaceous and Paleogene. Geology, 28 243-246.

Dutton, A., Wilkinson, B. H., Welker, J. M., Bowen, G. J. \& LohmanN, K. C. 2005. Spatial distribution and seasonal variation in ${ }^{18} \mathrm{O} /{ }^{16} \mathrm{O}$ of modern precipitation and river water across the conterminous USA Hydrological Processes, 19, 4121-4146.

Fiorillo, A. R., McCarthy, P. J. et al. 2010a. Paleontology and paleoenvironmental interpretation of the Kikak-Tegoseak Quarry (Prince Creek Formation: Late Cretaceous), Northern Alaska: a multidisciplinary study of a high-latitude ceratopsian dinosaur bonebed. In: Ryan, M. J., Cinnery-Allgeier, B. J. \& Eberth, D. A. (eds) New Perspectives on Horned Dinosaurs: The Royal Tyrrell Museum Ceratopsian Symposium. Indiana University Press, Bloomington, 456-477.

Fiorillo, A. R., McCarthy, P. J. \& Flaig, P. P. $2010 b$. Taphonomic and sedimentologic interpretations of the dinosaur-bearing Upper Cretaceous Strata of the Prince Creek Formation, Northern Alaska: insights from an ancient high-latitude terrestrial ecosystem.
Palaeogeography, Palaeoclimatology, Palaeoecology, 295, 376-388.

Flaig, P. P. 2010. Depositional environments of the Late Cretaceous (Maastrichtian) dinosaurs-bearing Prince Creek Formation: Colville River Region, North Slope, Alaska. $\mathrm{PhD}$ thesis, University of Alaska Fairbanks.

Flaig, P. P., McCarthy, P. J. \& Fiorillo, A. R. 2013. Anatomy, evolution and paleoenvironmental interpretation of an ancient arctic coastal plain: integrated paleopedology and palynology from the Upper Cretaceous (Maastrichtian) Prince Creek Formation, North Slope, Alaska, USA. In: Driese, S. G. \& Nordt, L. C. (eds) New Frontiers in Paleopedology and Terrestrial Paleoclimatology: Paleosols and Soil Surface Analogue Systems. SEPM Special Publications, Tulsa, 104, 179-230.

Flaig, P. P., McCarthy, P. J. \& Fiorillo, A. R. 2011. A tidally influenced, high-latitude coastal plain: the Upper Cretaceous (Maastrichtian) Prince Creek Formation, North Slope, Alaska. In: DAvidson, S., Leleu, S. \& North, C. (eds) From River to Rock Record: The Preservation of Fluvial Sediments and their Subsequent Interpretation. SEPM Special Publications, Tulsa, 97, 233-264.

Frank, T. \& Arthur, M. 1999. Tectonic forcings of Maastrichtian ocean-climate evolution. Paleoceanography, 14, 103-117.

FrederiKSEN, N. O. 1990. Pollen zonation and correlation of Maastrichtian marine beds and associated strata, Ocean Point dinosaur locality, North Slope, Alaska. US Geological Survey Bulletin, 1990-E, 1-24.

Fricke, H. C. \& Rogers, R. R. 2000. Multiple taxonmultiple locality approach to providing oxygen isotope evidence for warm-blooded theropod dinosaurs. Geology, 28, 799-802.

Fricke, H. C., Hencecroth, J. \& Hoerner, M. E. 2011. Lowland-upland migration of sauropods dinosaurs during the Late Jurassic epoch. Nature, 480, 513-515.

Fricke, H. C., Rogers, R. R., Backlund, R., Dwyer, C. N. \& EchT, S. 2008. Preservation of primary stable isotope signals in dinosaur remains, and environmental gradients of the Late Cretaceous of Montana and Alberta. Palaeogeography, Palaeoclimatology, Palaeoecology, 266, 13-27.

Gangloff, R. A. \& Fiorillo, A. R. 2010. Taphonomy and paleoecology of a bonebed from the Prince Creek Formation, North Slope, Alaska. Palaios, 25, 299-317.

Graversen, R. G., Mauritsen, T., Tuernström, Källén, E. \& Svensson, G. 2008. Vertical structure of recent Arctic warming. Nature, 541, 53-56.

Glimcher, M. 2006. Bone: nature of the calcium phosphate crystals and cellular, structural, and physical chemical mechanisms in their formation. Reviews in Mineralogy and Geochemistry, 64, 223-282.

Halas, S., Skrzypek, G. M.,, Meier-Augenstein, W., Pelc, A. \& Kemp, H. F. 2011. Inter-laboratory calibration of new silver orthophosphate comparison materials for the stable oxygen isotope analysis of phosphates. Rapid Communications in Mass Spectrometry, 25, 579-584.

Hay, W. W. \& DeConto, R. M. 1999. A comparison of modern and Late Cretaceous meridional energy trans- 


\section{ARCTIC PALAEOHYDROLOGY OF THE CRETACEOUS}

port and oceanology. In: BARRERA, E. \& JoHnSON, C. (eds) Evolution of the Cretaceous Ocean/Climate System. Geological Society of America, Special Papers, 332, 283-300.

Hays, P. D. \& Grossman, E. L. 1991. Oxygen isotopes in meteoric calcite cements as indicators of continental paleoclimate. Geology, 19, 441-444.

Hofmann, C., Feraud, G. \& Courtillot, V. 2000. ${ }^{40} \mathrm{Ar} /{ }^{39} \mathrm{Ar}$ dating of mineral separates and whole rocks from the western Ghats lava pile: further constraints on duration and age of Deccan traps. Earth and Planetary Science Letters, 180, 13-27.

Iacumin, P., Bocherens, H., Mariotti, A. \& LongiNELLI, A. 1996. Oxygen isotope analyses of co-existing carbonate and phosphate in biogenic apatite: a way to monitor diagenetic alteration of bone phosphate? Earth and Planetary Science Letters, 142, 1-6.

IAEA. 1992. Statistical treatment of data on environmental isotopes in precipitation. Technical Report No. 331. International Atomic Energy Agency, Vienna.

Jahren, A. H., Byrne, M. C., GrahaM, H. V., SternBERG, S. L. \& Summons, R. E. 2009. The environmental water of the middle Eocene Arctic: evidence from $\delta \mathrm{D}, \delta^{18} \mathrm{O}$ and $\delta^{13} \mathrm{C}$ within specific compounds. Palaeogeography, Palaeoclimatology, Palaeoecology, 271, 96-103.

Jenkyns, H. C., Forster, A., Schouten, S. \& Sinninghe Damasté, J. S. 2004. High temperatures in the Late Cretaceous Arctic Ocean. Nature, 432, 888-892.

Keller, G. 2001. The end-Cretaceous mass extinction in the marine realm: year 2000 assessment. Planetary and Space Science, 49, 817-830.

KIEHL, J. 2011. Lessons from Earth's past. Science, 331, $158-159$

KoHN, M. J. 1996. Predicting animal $\delta^{18} \mathrm{O}$ : accounting for diet and physiological adaptation. Geochimica et Cosmochimica Acta, 60, 4811-4829.

Kohn, M. J. \& Dettman, D. L. 2007. Paleoaltimetry from stable isotope compositions of fossils. Reviews in Mineralogy and Geochemistry, 66, 119-154.

Kolodny, Y., Luz, B., Sander, M. \& Clemens, W. A. 1996. Dinosaur bones: fossils or pseudomorphs? The pitfalls of physiology reconstruction from apatitic fossils. Palaeogeography, Palaeoclimatology, Palaeoecology, 126, 161-171.

LÉCUYER, C. 2004. Oxygen isotope analysis of phosphate. In: DE GRooT, P. (ed.) Handbook of Stable Isotope Analytical Techniques. Elsevier, Amsterdam, 1, 482-496.

Lécuyer, C., Bogey, C. ET AL. 2003. Stable isotope composition and rare earth element content of vertebrate remains from the Late Cretaceous of northern Spain (Laño): did the environmental record survive? Palaeogeography, Palaeoclimatology, Palaeoecology, 193, $457-471$.

Lécuyer, C., Fourel, F. et aL. 2007. High-precision determination of ${ }^{18} \mathrm{O} /{ }^{16} \mathrm{O}$ ratios of silver phosphate by EA-pyrolysis-IRMS continuous flow technique. Journal of Mass Spectrometry, 42, 36-41.

Levin, N. E., Cerling, T. E., Passey, B. H., Harris, J. M. \& Ehleringer, J. R. 2006. A stable isotope aridity index for terrestrial environments. Proceedings of the National Academies of Science of the USA, 103, $11201-11205$.
LI, L. \& Keller, G. 1998. Abrupt deep-sea warming at the end of the Cretaceous. Geology, 26, 995-998.

Lohmann, K. C. 1988. Geochemical patterns of meteoric diagenetic systems and their application to studies of paleokarst. In: JAmes, N. P. \& Choquette, P. W. (eds) Paleokarst. Springer, New York, 58-80.

Ludvigson, G., González, L. A., Metzger, R. A., Witzke, B. J., Brenner, R. L., Murillo, A. P. \& White, T. S. 1998. Meteoric sphaerosiderite lines and their use for paleohydrology and paleoclimatology. Geology, 26, 1039-1042.

MarkwICK, J. 1998. Fossil crocodilians as indicators of Late Cretaceous and Cenozoic climates: implications for using palaeontological data in reconstructing palaeoclimate. Palaeogeography, Palaeoclimatology, Palaeoecology, 137, 205-271.

McKay, M. E. P. 2008. Paleoecologies of the mammalian fossils from fossil faunas of Natural Trap Cave and Little Box Elder Cave, Wyoming. MS thesis, University of South Carolina.

Nordt, L., Atchley, S. \& Dworkin, S. 2003. Terrestrial evidence for two greenhouse events in the latest Cretaceous. GSA Today, 13, 4-9.

O’Neil, J. R., Roe, R. R., Reinhard, E. \& Blake, R. E. 1994. A rapid and precise method of oxygen isotope analysis of biogenic phosphate. Israel Journal of Earth-Sciences, 43, 203-212.

Pagani, M., Pedentchouk, N. ET AL. the Expedition 302 Scientists. 2006. Arctic hydrology during global warming at the Paleocene/Eocene thermal maximum. Nature, 442, 671-675.

PARrish, J. T. \& SpICER, R. A. 1988. Late Cretaceous terrestrial vegetation: a near-polar temperature curve. Geology, 16, 22-25.

Parrish, M. J., Parrish, J. T., Hutchinson, H. \& Spicer, R. A. 1987. Late Cretaceous vertebrate fossils from the North Slope of Alaska and implications for dinosaur ecology. Palaios, 2, 377-389.

Phillips, R. L. 2003. Depositionl environments and processes in Upper Cretaceous nonmarine and marine sediments, Ocean Point dinosaur locality, North Slope, Alaska. Cretaceous Research, 24, 499-523.

Poulsen, C. J., Pollard, D. \& White, T. S. 2007. General circulation model simulation of the $\delta^{18} \mathrm{O}$ content of continental precipitation in the middle Cretaceous: a model-proxy comparison. Geology, 35, 199-202.

Pucéat, E., Lécuyer, C. ET aL. 2007. Fish tooth $\delta^{18} \mathrm{O}$ revising Late Cretaceous meridional upper ocean water temperature gradients. Geology, $\mathbf{3 5}$, $107-110$.

Rich, T. H., Vickers-Rich, P. \& Gangloff, R. A. 2002. Polar dinosaurs. Science, 295, 979-980.

Sharp, Z. D., Atudorei, V. \& Furrer, H. 2000. The effect of diagenesis on oxygen isotope ratios of biogenic phosphates. American Journal of Science, 300, 222-237.

SPICER, R. A. 2003. Changing climate and biota. In: Skelton, P., Sicer, R. A., Kelley, S. \& Gilmour, I. (eds) The Cretaceous World. Cambridge University Press, Cambridge, 85-162.

Spicer, R. A. \& Corfield, R. M. 1992. A review of terrestrial and marine climates in the Cretaceous with implications for modeling the 'Greenhouse Earth.' Geological Magazine, 2, 169-180. 


\section{A. SUAREZ ET AL.}

Spicer, R. A. \& Herman, A. B. 2010. The Late Cretaceous environment of the Arctic: a quantitative reassessment based on plant fossils. Palaeogeography, Palaeoclimatology, Palaeoecology, 295, 423-442.

Spicer, R. A. \& Parrish, J. T. 1990. Late Cretaceousearly Tertiary paleoclimates of northern high latitudes: a quantitative view. Journal of the Geological Society, London, 147, 329-341.

Suarez, M. B., González, L. A., Ludvigson, G. A., Vega, F. J. \& Alvarado-Ortega, J. 2009. Isotopic composition of low-latitude paleoprecipitation during the Early Cretaceous. Geological Society of America Bulletin, 121, 1584-1595.

Suarez, M. B., Gonzalez, L. A. \& Ludvigson, G. A. 2010. Estimating the oxygen isotopic composition of equatorial precipitation during the mid-Cretaceous. Journal of Sedimentary Research, 80, 480-491.

Suarez, M. B., Gonzalez, L. A. \& Ludvigson, G. A. 2011. Quantification of greenhouse hydrologic cycle from equatorial to polar latitudes: the mid-Cretaceous water bearer revisited. Palaeogeography, Palaeoclimatology, Palaeoecology, 307, 302-312.

Suarez, C. A., Gonzalez, L. A., Ludvigson, G. A., Cifelli, R. L. \& Tremain, R. 2012. Water utilization of the Cretaceous Mussentuchit Member local vertebrate fauna, Cedar Mountain Formation, Utah, USA: using oxygen isotopic composition of phosphate. Palaeogeography, Palaeoclimatology, Palaeoeclogy, 313-314, 78-92, http://dx.doi.org/10.1016/ j.palaeo.2011.10.011.

Tarduno, J. A., Brinkman, D. B., Renne, P. R., CotTRELl, R. D., SCHER, H. \& CASTILlo, P. 1998. Evidence for extreme climatic warmth from Late Cretaceous Arctic vertebrates. Science, 282, 2241-2244.

Ufnar, D. F., González, L. A., Ludvigson, G. A. Brenner, R. L. \& Witzke, B. J. 2002. The midCretaceous water bearer: isotope mass balance quantification of the Albian hydrologic cycle. Palaeogeography, Palaeoclimatology, Palaeoecology, 188, 51-71.

Ufnar, D. F., González, L. A., Ludvigson, G. A., Brenner, R. L. \& Witzke, B. J. 2004a. High latitude meteoric $\delta^{18} \mathrm{O}$ compositions: paleosol siderite in middle Cretaceous Nanushuk Formation, North Slope, Alaska. GSA Bulletin, 116, 463-473.
Ufnar, D. F., González, L. A., Ludvigson, G. A., BrenNer, R. L. \& WitZKe, B. J. 2004b. Evidence for increased latent heat transport during the Cretaceous (Albian) greenhouse warming. Geology, 32, 1049-1052.

Vandermark, D., Tarduno, J. A. \& Brinkman, D. B. 2007. Fossil champsosaur population from the high Arctic: implications for Late Cretaceous paleotemperatures. Palaeogeography, Palaeoclimatology, Palaeoecology, 248, 49-59.

Vennemann, T. W. 2012. Further comparison of methods of oxygen isotope analysis of phosphates and standards use. IsoPhos 2012 Annual Meeting, 25-29 June, Asconda, Switzerland.

Vennemann, T. W., Fricke, H. C., Blake, R. E., O'Neil, J. R. \& Colman, A. 2002. Oxygen isotope analysis of phosphates: a comparison of techniques for analysis of $\mathrm{Ag}_{3} \mathrm{PO}_{4}$. Chemical Geology, 185, 321-336.

Vogl, J. J., Calvert, A. T. \& Ganus, P. B. 2002. Mechanisms and timing of exhumation of collision-related metamorphic rocks, Southern Brooks Range, Alaska: insights from ${ }^{40} \mathrm{Ar} /{ }^{39} \mathrm{Ar}$ thermochronology. Tectonics, 21, 18, http://dx.doi.org/10.1029/2000TC001270.

Wilf, P., Johnson, K. R. \& Huber, B. T. 2003. Correlated terrestrial and marine evidence for global climate changes before mass extinction at the Cretaceous-Paleogene boundary. Proceedings of the National Academy of Sciences of the USA, 100, 599-604.

Witte, K. W., Stone, D. B. \& Mull, C. G. 1987. Paleomagnetism, paleobotany, and paleogeography of the Cretaceous, North Slope, Alaska. In: TAIILEUR, I. \& Weimer, P. (eds) Field Trip Guidebook - Pacific Section, Society of Economic Paleontologists and Mineralogists, Los Angeles, CA, 50, 571-579.

Wolfe, J. A. \& UPChURCH, G. J. R. 1987. North American non-marine climates and vegetation during the Late Cretaceous. Palaeogeography, Palaeoclimatology, Palaeoecology, 61, 31-77.

Zazzo, A., Lécuyer, C., Sheppard, S. M. F., GrandJeAn, P. \& Mariotti, A. 2004. Diagenesis and the reconstruction of paleoenvironments: a method to restore original $\delta^{18} \mathrm{O}$ values of carbonate and phosphate from fossil tooth enamel. Geochimica et Cosmochimica Acta, 68, 2245-2258. 